\title{
稲田花崗岩の破壊強度以降も含めた応力ーひず久特性 に関する基礎的研究
}

甲 村 雄 一*

\section{A Fundamental Study on Stress-Strain Characterization of Inada Granite Including Post-Failure Region}

by

\author{
Yuichi KoHMURA*
}

\begin{abstract}
In this study the uni-axial compression test using the stress-feedback method was carried out with Inada granite which is a Class II rock. The test was carried out by changing loading direction and water content conditions. A perfect stress-strain curve was measured. The stress-strain curve including the post-failure region was simulated using a spring model. In addition, the effects of anisotropy and water content conditions on the stress strain characterization were examined.
\end{abstract}

Key words : Post-failure region, Stress-strain characterization, Granite, Anisotropy, Water content

\section{1 緒 言}

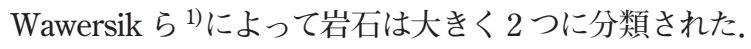
すなわち, 定ひずみ速度試験でピーク応力以降も圧縮試 験が制御できる Class I 岩石と, 制御できない Class II 岩 石である. Class II 岩石では破壊強度以降の応力ーひず み曲線が正の傾きを示すため，定ひずみ速度試験で破壊 強度を過ぎると急激に破壊が生じる。このような挙動は 山はねなどの急激な破壊現象と関連していることが予想 されている.2)

大久保らは応力帰還法 ${ }^{3)}$ による試験方法を提案し, 岩 石の一軸圧縮試験 ${ }^{3)}$ や三軸圧縮試験 ${ }^{4)}$ を実施して, 破壊 強度から残留強度に至るまでの完全応力ーひずみ曲線を 計測し，その挙動に関して検討するとともにコンプライ アンス可変型の構成式を提案している。稲田ら ${ }^{5)}$ は, 応 力帰還法を応用した試験方法により, 種々の岩石の高温 下扎よび低温下での破壊強度以降の応力ーひずみ挙動を 計測している. 残留強度まで含めた完全応力ーひずみ曲 線の計測までには至っていないが, 破壊強度以降の応 カーひずみ曲線に, 温度が与える影響について検討して いる.

一方で，斎藤ら ${ }^{6)}$ は載荷軸に垂直な方向である横方向 変形で試験を制御することで, 破壊強度以降の応力ーひ ずみ曲線を計測し, 岩石が Class II となる条件について 考察している。長ら ${ }^{7)}$ は横方向変形制御で試験を行い, Post-failure 領域を応力の降下速度が異なる 3 つの領域に 分類している.

しかしながら，破壊強度以降における応力一ひずみ特 性に関する研究例は, 破壊強度までの挙動の研究例に比 べて少ない，たとえば, 破壊強度までの応力一ひずみ挙動 に関しては, 載荷方向に関する異方性に関する研究 ${ }^{8)}$ 10) や，含水状態が破壊強度に及ぼす影響に関する研究 11), 12)
\end{abstract}

が多くみられるが, 破壊強度以降に関しては含水状態に 関する研究例が 1 例 ${ }^{5)}$ みられるだけであり，異方性に関 する研究例は見あたらない.

本研究では, Class II 岩石の一つである稲田花崗岩を 用いて，応力帰還法による一軸圧縮試験を実施した。そ の際，石の目に対する載荷方向および含水状態を変えた 試験を実施し，完全応力一ひずみ曲線を計測した。また， ばねモデルにより破壊強度以降も含めた応力ーひずみ曲 線のシミュレーションを実施し, 石の目に対して載荷方 向が異なることによる異方性や含水状態が応力ーひずみ 挙動に及ぼす影響について考察を行った結果について述 ベる.

\section{2 試 験 方 法}

試験に用いた岩石は, 茨城県笠間市産の通称稲田花崗 岩である。花崗岩にはマイクロクラックの配向性に起因 する異方性がみられ，最も割れやすい面を Rift-plane，そ れに直交し 2 番目に割れやすい面を Grain-plane および これらに垂直な面を Hardway-plane と呼ぶ. ${ }^{13)}$ 岩石は採石 場から約 $250 \mathrm{~mm}$ 角の大きさで切り出し，その各面が現 地で経験的に知られている Rift-plane, Grain-plane およ び Hardway-plane に一致するようにした。 供試体の寸法 は直径 $35 \mathrm{~mm}$, 高さ $70 \mathrm{~mm}$ とし, Rift-plane に垂直な方 向（以下 R 方向と呼ぶ）扎よび Hardway-plane に垂直な 方向（以下 $\mathrm{H}$ 方向と呼ぶ）に作製した。供試体の端面は 特に留意して成形し，高低差を $1 / 100 \mathrm{~mm}$ 以内に抑えた。 成形後の供試体は室内で 1 週間自然乾燥させた後, デシ ケータ内で 3 カ月間乾燥させた。これをDry 供試体と呼 ぶ.また，供試体をデシケータ内で水潤させた状態で真 空ポンプを併用して 24 時間抜気したものをWet 供試体 と呼ぶ. 供試体の物理的性質を Table 1 に示す.

試験は油圧サーボ試験機（MTS 社製，815 Rock mechan-

$\dagger$ 原稿受理 平成 23 年 5 月 23 日 Received May 23, 2011 C 2012 The Society of Materials Science, Japan

* 正会員 (踭竹中工務店技術研究所 于270-1395 印西市大塚, Takenaka R \& D Inst., Ohtsuka, Inzai, 270-1395 
Table 1 Physical properties of specimen.

\begin{tabular}{l|c|c|c}
\hline \multicolumn{2}{c|}{} & $\begin{array}{c}\text { P-wave velocity } \\
(\mathrm{km} / \mathrm{s})\end{array}$ & $\begin{array}{c}\text { Density } \\
\left(\mathrm{g} / \mathrm{cm}^{3}\right)\end{array}$ \\
\hline R-direction & Dry & 4.30 & \multirow{2}{*}{2.619} \\
\hline \multirow{2}{*}{ H-direction } & Dry & 4.62 & \\
\cline { 2 - 4 } & Wet & 6.03 & 2.627 \\
\hline
\end{tabular}

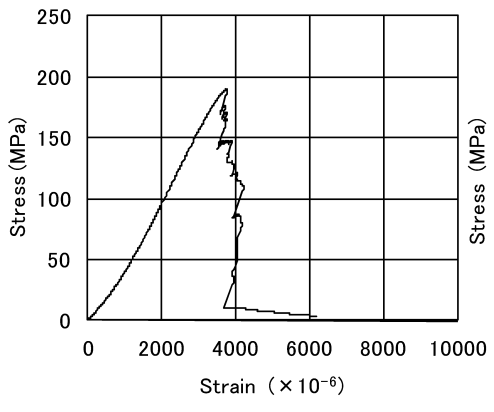

(a) Extensometer

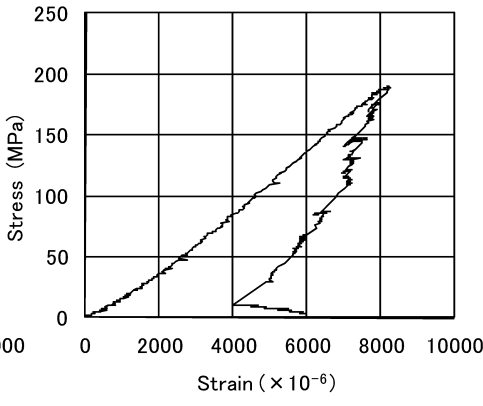

(b) Piston displacement

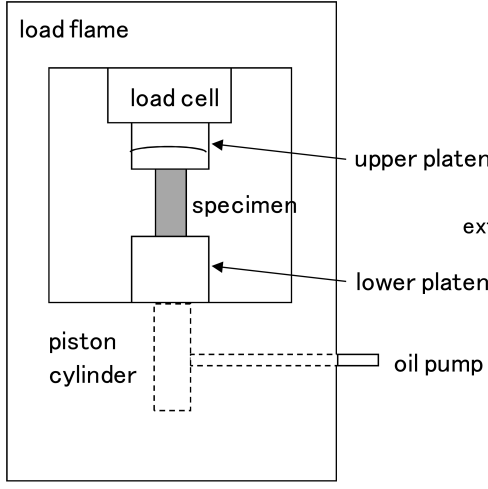

(b) Load flame

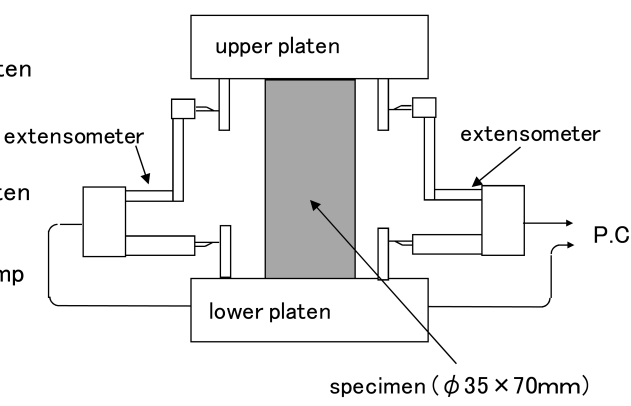

(b) Extensometer

Fig. 2 Stress-strain curves of specimen.

Table 2 Compressive strength.

\begin{tabular}{l|c|c}
\hline \multicolumn{2}{c|}{} & $\begin{array}{c}\text { Compressive } \\
\text { strength } \\
(\mathrm{MPa})\end{array}$ \\
\hline R-direction & Dry & 209 \\
\hline \multirow{2}{*}{$\mathrm{H}$-direction } & Dry & 190 \\
\cline { 2 - 3 } & Wet & 169 \\
\hline
\end{tabular}

Fig. 1 Schematic diagram of the tests.

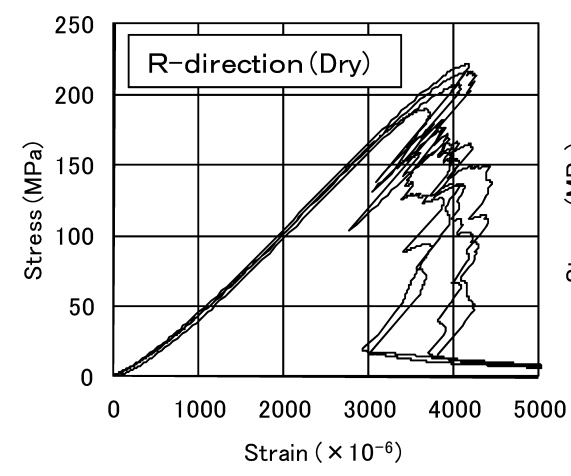

(a) R-direction(Dry)

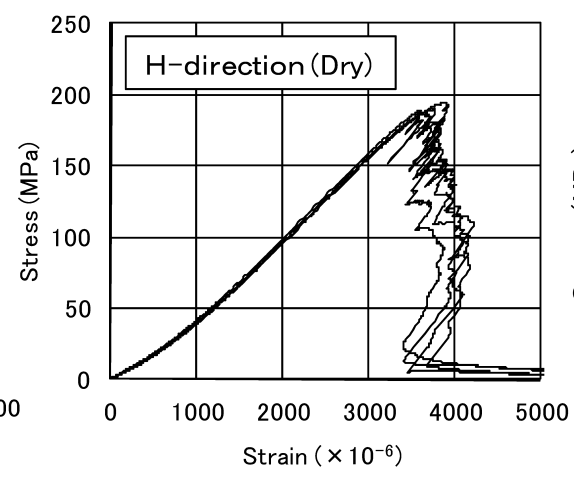

(b) H-direction(Dry)

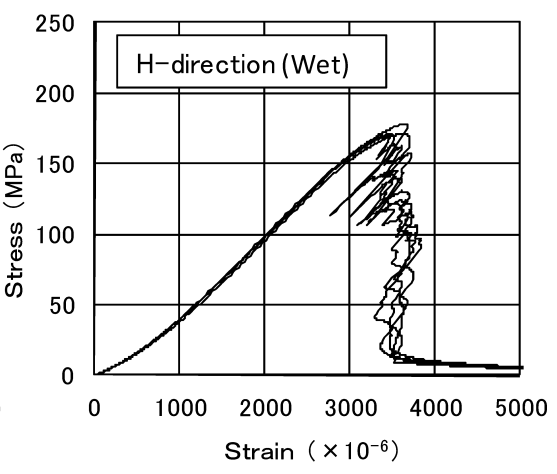

(c) H-direction(Wet)

Fig. 3 Stress-strain curves of specimen.

ics test system）を用いて実施した。試験は式 (1)に示す 応力帰還法 ${ }^{3)}$ で制御した.

$$
\varepsilon-\sigma / \mathrm{E}=\mathrm{C} \cdot \mathrm{t}
$$

ここで, $\varepsilon$ は載荷軸方向のひずみ, $\sigma$ は載荷軸方向の応 力, $\mathrm{E}$ は制御の傾き, $\mathrm{C}$ は載荷速度を決める值および $\mathrm{t}$ は時間である。試験を安定して実施するためには， E と Cの值を適切に設定する必要がある。予備実験を実施し て, 安定して試験結果が得られる条件として，C=3.5× $10^{-6} / \mathrm{s} ， \mathrm{E}$ に関しては R 方向では $67.2 \mathrm{GPa}, \mathrm{H}$ 方向では $70 \mathrm{GPa}$ とした。試験装置の概念困を Fig. 1 (a)，(b)に示 す。応力は, 供試体上部に設置したロードセルで得られ た荷重を，供試体の初期断面積で除すことによって求め た。また，載荷軸方向のひずみは上下加圧盤に治具を取 り付け，これに測定間隔 $50 \mathrm{~mm}$ のひずみ計を対面状に 2 個取り付け，その平均ひずみを供試体高さ分のひずみに
補正して求めた。なお，油圧サーボ試験機の油圧ピスト ンシリンダー部のピストン変位からも, 載荷軸方向のひず みを計算によって求めることができる。両者を比較したも のを Fig. 2 (a)， (b)に示す. 両者で值が大きく異なった. これは，ピストン変位から求めたひずみは，ロードフレー ム, ロードセルおよび加圧盤等のひずみの影響を受けた 值であるためと考えられる。このため，載荷軸方向のひ ずみの測定は前者の方法に統一した。

\section{3 試 験 結 果}

\section{$3 \cdot 1$ 破壊強度までの応力ーひずみ特性}

各条件で 4 本の供試体の試験を行って得られた一軸圧 縮強度の平均值を Table 2 に, 完全応力ーひずみ曲線を Fig. 3 に示す. Dry 供試体を用いた 2 つの条件を比較す ると, $\mathrm{R}$ 方向に比べて $\mathrm{H}$ 方向で一軸圧縮強度が小さく, 破壊強度の異方性を示すことが確認できた。また， H 方 
向に載荷した $2 つ の$ 条件を比較するとDry 供試体に比べ てWet 供試体の方が一軸圧縮強度が小さく，破壊強度は 含水状態の影響を受けることが碓認できた。それでれの 条件で応力レベルごとに接線ヤング率を求めた結果を Fig. 4 に示す. 各条件とも接線ヤング率の值は応力レベ ルによって異なり，応力レベルの増加とともに值が増加 し，極大值を示した後に減少に転じる。これは，応力レ ベルが小さい段階では岩石中に含まれるマイクロクラッ クが閉塞していくことによりヤング率が増加していくこ と, また, 応力レべルが大きい段階では岩石内部で微視 的な破壊が進行していくことによりヤング率が低下してい くことに起因しているものと考えられる.14)先に述べたよ うに，一軸圧縮強度は各条件で值が異なったが，接線ヤ ング率の極大值は 3 つの条件で大きな差は見られず，ほ ぼ同じ值を示すことがわかった。これは，Dry 供試体打 よびWet 供試体ともに，接線ヤング率が極大值を示す応 力では, マイクロクラックの閉塞がほぼ終了し, クラック 部も含めた全断面で（Wet 供試体では水を介してクラッ ク全断面で）圧縮荷重を支持しているものと考元られる. このため，接線ヤング率の極大值に大きな差が見られな かったものと推察される。

\section{$3 \cdot 2$ 破壊強度以降の応力ーひずみ特性}

Fig. 3 に示したように，破壊強度以前ではそれぞれの 条件で応力ーひずみ曲線がよく一致しているのに対し， 破壊強度以降では応力ーひずみ曲線のばらつきが大きい． これは破壞強度に達した後も, 応力の変化に伴い破壊が 進行していき，供試体間で破壊の状態にばらつきが生じ るためと考えられる。破壞強度以降の試験中には, 応力 の低下とともに供試体から小片が音を立てて剥がれおち ながら破壊が進行し, その後, 安定してひずみが増加す る残留強度へと至った。

破壊強度に打けるひずみを 0 として, 破壊強度以降の 経過時間とひずみとの関係の代表例を Fig. 5 に示す. 時 間の経過とともに，ひずみは増加（収縮）と減少（膨張） を繰り返しながら破壊が進行していき, 約 640s 後に安定 してひずみか増加する残留強度状態へと至った. Class II 岩石の特徵は, 破壞強度以降に打いて応力の低下ととも にひずみが減少することである。ひずみの増加に比べて， ひずみの減少は短時間で生じ, この際，供試体から小片 が音を立てて剥がれ打ちた。各条件でひずみの減少量の

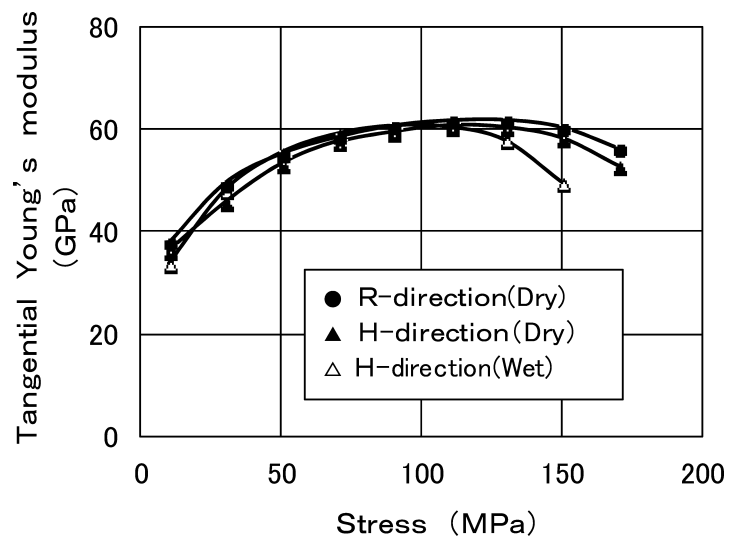

Fig. 4 Tengential Young's modulus of specimen.

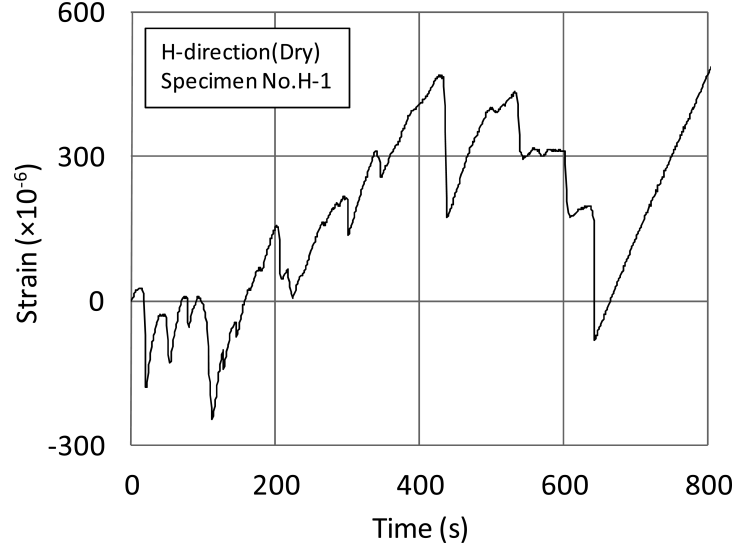

Fig. 5 Relation between time and strain.

累積值を求めた結果を Table 3 に示す。ひずみの減少量 の累積值とは, ピーク応力から残留強度状態に至るまで の間に, ひずみが減少した区間のひずみの絶対值を合計 したものである. 各条件での比較を行うため, Table 3 にはひずみの減少量の累積值を破壊強度に打けるひずみ で除して正規化した值を示した。供試体間での值のばら つきが大きいが，Dry 供試体を比較すると， H 方向に比 べて R 方向でひずみの減少が大きいことがわかった。ま た， H 方向を比較すると Wet 供試体に比べて Dry 供試 体の方が值が大きいことがわかった。

\section{$4 \cdot 1$ ばねモデルの概要}

\section{4 試験結果の考察}

何ら ${ }^{15)}$ は，岩石の Class II 特性を説明するモデルとし て, Fig. 6 に示すように並列ばねモデルを直列に 2 段つ ないだモデルを提案している。 また，このモデルに扔い

Table 3 An accumulated decrease strain.

\begin{tabular}{|c|c|c|c|c|c|c|}
\hline \multicolumn{2}{|c|}{ Specimen number } & 1 & 2 & 3 & 4 & Mean \\
\hline \multirow{3}{*}{$\begin{array}{l}\text { R-direction } \\
\text { (Dry) }\end{array}$} & $\begin{array}{c}\text { (a) An accumulateed } \\
\text { decrease strain }\end{array}$ & 3626 & 2906 & 3013 & 2632 & 3044 \\
\hline & \begin{tabular}{|l|} 
(b) Strain of peak \\
stress
\end{tabular} & 4168 & 4052 & 4190 & 3669 & 4020 \\
\hline & (a) $/(b)$ & 0.870 & 0.717 & 0.719 & 0.717 & 0.756 \\
\hline \multirow{3}{*}{$\begin{array}{l}\text { H-direction } \\
\text { (Dry) }\end{array}$} & $\begin{array}{c}\text { (a) An accumulateed } \\
\text { decrease strain }\end{array}$ & 1989 & 2397 & 3228 & 1792 & 2352 \\
\hline & \begin{tabular}{|l} 
(b) Strain of peak \\
stress
\end{tabular} & 3747 & 3863 & 3600 & 3664 & 3719 \\
\hline & (a)/(b) & 0.531 & 0.621 & 0.897 & 0.489 & 0.634 \\
\hline \multirow{3}{*}{$\begin{array}{c}\mathrm{H}-\text { direction } \\
(\text { Wet })\end{array}$} & $\begin{array}{c}\text { (a) An accumulateed } \\
\text { decrease strain }\end{array}$ & 2410 & 1669 & 2285 & 1760 & 2031 \\
\hline & $\begin{array}{l}\text { (b) Strain of peak } \\
\text { stress }\end{array}$ & 3656 & 3451 & 3445 & 3572 & 3531 \\
\hline & (a) $/(b)$ & 0.659 & 0.484 & 0.663 & 0.493 & 0.575 \\
\hline
\end{tabular}

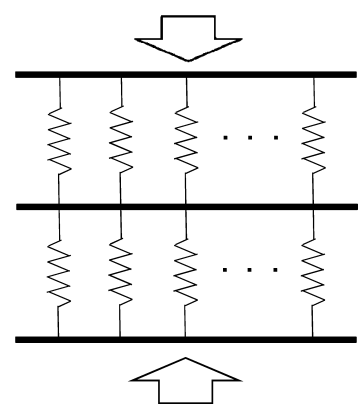

Fig. 6 Schematic diagram of spring model. ${ }^{15}$ 


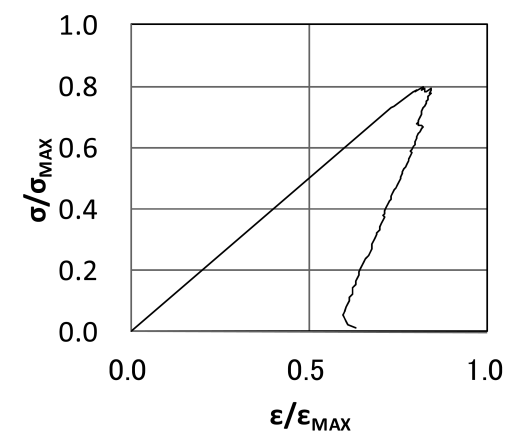

(a) coefficient of variation :0.1

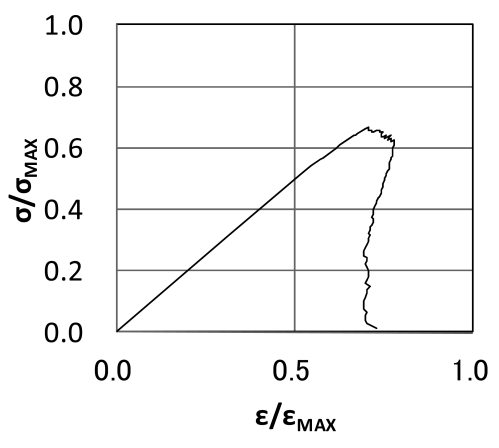

(b) coefficient of variation :0.2

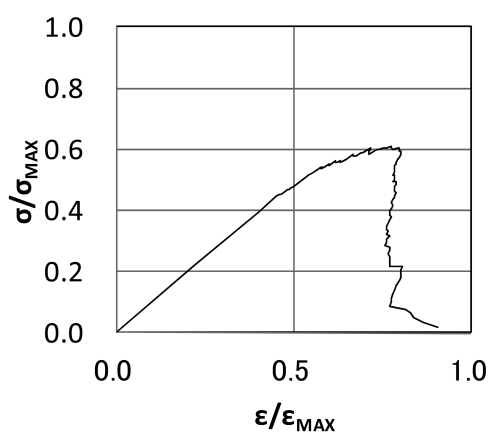

(c) coefficient of variation :0.3

Fig. 7 Stress-strain curves obtained by spring model.

て, 各段のばねの数を 100 個とし, 各ばねの破壊強度は正 規分布に従うとして応力ーひずみ挙動のシミュレーション を行っている. シミュレーション方法を引用すると以下 のと打りである.

1）正規乱数を発生させて各ばねに破壊強度を割り当 てる.

2）各段の未破壊のばねのうち, 最小の強度 $\sigma_{\mathrm{MIN}}$ を 持つばねを探し, 各段の耐荷能力 $\mathrm{F}_{\mathrm{i}}=\sigma_{\mathrm{MIN}} \cdot \mathrm{N}_{\mathrm{i}}$ $(\mathrm{i}=1,2)$ を計算する．ただし， $\mathrm{N}_{\mathrm{i}}$ は $\mathrm{i}$ 段の未破壊 要素の数である.

3) $\mathrm{F}_{1}$ と $\mathrm{F}_{2}$ を比べ, 小さい方を耐荷能力 $\mathrm{F}_{\mathrm{CA}}$ とする.

4）モデルのばね定数 $\mathrm{K}$, 変位 $\mathrm{D}$ を次式で求める.

$$
\mathrm{K}=1 /\left(\mathrm{K}_{1}^{-1}+\mathrm{K}_{2}^{-1}\right), \mathrm{D}=\mathrm{F}_{\mathrm{CA}} / \mathrm{K}
$$

ただし， $\mathrm{K}_{\mathrm{i}}$ は各段のばね定数で, 未破壊要素の数 $\mathrm{N}_{\mathrm{i}}(\mathrm{i}=1,2)$ に比例する.

5）荷重 $\mathrm{F}_{\mathrm{CA}}$ で破壊限界に達した要素のばね定数を 0 として2)に戻る。

本研究においても各段のばねの数は 100 個とした.ば ねの平均強度を $0.5 \mathrm{MPa}$ とし, 各段のばねにおける最大 応力 $\sigma_{\mathrm{MAX}}$ は $0.5 \mathrm{MPa} \times 100=50 \mathrm{MPa}$ とした。ばねの強度 の変動係数を $0.1 ， 0.2$ 打よび 0.3 として, $0 \mathrm{MPa} \sim 1 \mathrm{MPa}$ の範囲で正規乱数を発生させて各ばねの強度を設定し， 応力ーひずみ挙動のシミュレーションを行った，得られ た応力ーひずみ曲線を Fig. 7 (a)〜 (c)に示す. 何ら ${ }^{15)}$ は 変動係数が小さいほど破壊強度以降でのひずみの減少が 大きくなり，顕著なClass II 特性を示すことを示してい るが, 当然のことながら本研究に打いても同じ結果が得 られた。 また, 本モデルでは, 変動係数が小さいほど破 壊強度は大きくなること, また, 変動係数が大きいほど 破壊強度以前の早い段階で応力ーひずみ曲線の傾きが小 さくなることがわかった．変動倸数が大きいほどばねの 強度のばらつきが大きくなり, ばねの強度が小さなもの を含むこととなる。このため，応力が小さい段階でばね の破壊が生じることから破壊強度の低下や, 応力が小さ い段階でのヤング率の低下が生じたものと考えられる. 以上のことから，本ばねモデルは以下のような特徴を有 していることがわかる.

1）ばねの強度の変動係数が小さいほど，破壊強度以 降のひずみの減少量が大きくなり，強いClass II 特性を示す。
2）ばねの強度の変動係数が小さいほど破壊強度が大 きい。

3）ばねの強度の変動係数が大きいほど，破壊強度以 前に打いて応力が小さい段階で応力ーひずみ曲線 の傾きが小さくなる.

\section{$4 \cdot 2$ 載荷方向異方性のばねモデルによる説明}

Table 3 に示したように，破壊強度以降に打いて Dry 供試体の $\mathrm{R}$ 方向と $\mathrm{H}$ 方向を比較すると， $\mathrm{R}$ 方向でひずみ の減少量の累積值が大きい，すなわち， $\mathrm{R}$ 方向で顕著な Class II 特性を示している。 また, Tabel 2 に示したよう にR方向で一軸圧縮強度が大きい．前述のばねモデルで これを説明しようとすると， $\mathrm{R}$ 方向は $\mathrm{H}$ 方向に比べてば ねの強度の変動係数が小さいとした場合に，ばねモデル の特徴 1)打よび2)を満足する。なお，Fig. 4 に示したよ うに，破壊強度以前の接線ヤング率の極大值は， $\mathrm{R}$ 方向 と H 方向で值に大きな差は見られないことがわかってい る。このため，ばねモデルのばねの強度の平均值は $\mathrm{R}$ 方 向打よび $\mathrm{H}$ 方向で同じと考えている.

$\mathrm{R}$ 方向と $\mathrm{H}$ 方向で，破壊強度に至るまでの間で，割線 ヤング率が最大值を示す応力を求めた結果を Fig. 8 に示 す。な打，ここでは接線ヤング率ではなく割線ヤング率 を示したが，これは接線ヤング率が極大值を示す応力を 正確に求めることが，データの精度上困難であったため である。図に示すように，割線ヤング率の最大值を示す 応力は $\mathrm{H}$ 方向の方が小さい. すなわち, $\mathrm{R}$ 方向に比べて $\mathrm{H}$ 方向の方が, 応力ーひずみ曲線の傾きが小さくなる応 力が小さいこととなり， $\mathrm{H}$ 方向の方がばねの強度の変動

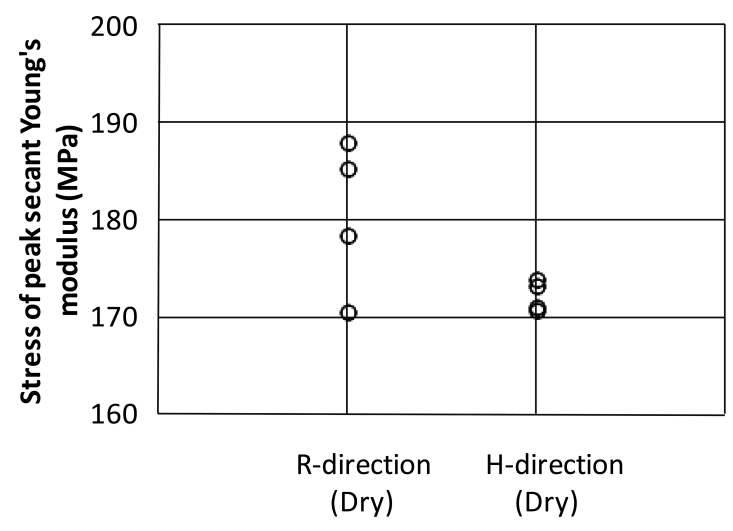

Fig. 8 Stress of peak secant Young's modulus. 
係数が大きい，すなわち R 方向でばねの強度の変動係数 が小さいことがわかる．以上のことから，前述したばね モデルの特徴 3)も満足しており，ばねモデルでばねの強 度の変動係数が異なるとした場合に，載荷方向異方性に 関する応力ーひずみ挙動を定性的に説明できることがわ かった．本ばねモデルは破壊応力以降はもちろんのこと， 破壊応力以前の挙動も定性的に説明できている．H 方向 に比べて R 方向でばねの変動係数が小さい理由の一つと して，マイクロクラックの配向性が考えられる。すなわ ち， $\mathrm{R}$ 方向に比較して $\mathrm{H}$ 方向は Table 1 に示したように 弾性波伝ぱ速度の值が大きい。このことからマイクロク ラックは $\mathrm{R}$ 方向に垂直な方向に, $\mathrm{H}$ 方向に平行な方向に 多く存在するものと考えられる．H方向に平行な方向に クラックが多く存在するため, $\mathrm{H}$ 方向は横方向に変形し やすく，例えば，三軸圧縮試験で周圧が小さい条件のよ うに, 見かけ上の横方向の拘束が小さく, 強度が小さく なると考えられる。このため， $\mathrm{H}$ 方向は強度の小さいば ねを多く含むことが原因の一つと考えられる.

なお， Table 3 に示したように，ひずみの減少量の累積 值を正規化した值は， R 方向で $0.756 ， \mathrm{H}$ 方向で 0.634 と 載荷方向により差がみられ，その差は $16 \%$ 程度であった。

\section{$4 \cdot 3$ 含水状態の違いのばねモデルによる説明}

Table 3 に示したように，破壊強度以降において $\mathrm{H}$ 方 向の Dry 供試体と Wet 供試体を比較すると，Dry 供試体 でひずみの減少量の累積值が大きい，すなわち，Dry 供 試体で顕著な Class II 特性を示している。 また，Tabel 2 に示したようにDry 供試体で一軸圧縮強度が大きい．前 述のばねモデルでこれを説明しようとすると，Dry 供試 体は Wet 供試体に比べてばねの強度の変動係数が小さい ことで，ばねモデルの特徴 1)および2)を満足する.

Dry 供試体と Wet 供試体で，破壊強度に至るまでの間 で, 割線ヤング率が最大值を示す応力を求めた結果を Fig. 9 に示す. 図に示すように, 割線ヤング率の最大值 を示す応力はWet 供試体の方が小さい. すなわち, Dry 供試体に比べて Wet 供試体の方が, 応力ーひずみ曲線の 傾きが小さくなる応力が小さいこととなり, Wet 供試体 の方がばねの強度の変動係数が大きい，すなわち Dry 供 試体でばねの強度の変動係数が小さいことがわかる．以 上のことから，前述したばねモデルの特徴 3)も満足して おり, ばねモデルでばねの強度の変動係数が異なるとし

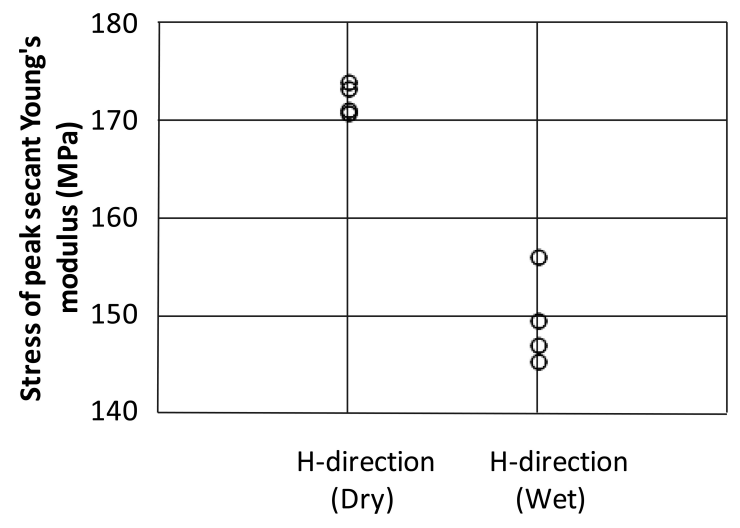

Fig. 9 Stress of peak secant Young's modulus.
た場合に，含水状態が異なる場合の応力ーひずみ挙動を 定性的に説明できることがわかった. Wet 供試体に比べ て Dry 供試体でばねの変動係数が小さい理由の一つとし て, Wet 供試体では応力の増加とともに過剩間隙水圧が 発生し，微視的破壊を助長すること等が考えられる。こ のため，強度の小さいばねを多く含むことが原因の一つ であると考えられる。

なお, Table 3 に示したように, ひずみの減少量の累 積值を正規化した值はDry 供試体で 0.634 , Wet 供試体 で 0.575 と差がみられ，その差は $9 \%$ 程度であった。載荷 方向異方性が，ピーク応力以降のひずみの減少量の累積 值を正規化した值に及ぼす影響は 16\%であったことと比 べると，含水状態が正規化した值に及ぼす影響はやや小 さいようである。このことから，ばねモデルにおいて，含 水状態が異なる場合のばねの強度の变動係数の差は，載 荷方向の異方性の場合に比べてやや小さいものと推察さ れる.

$4 \cdot 2$ 節および本節で述べたように，載荷方向異方性や 含水状態が異なる場合の応力ーひずみ挙動の特徴を, Fig. 6 に示した単純なばねモデルを用いて，ばねの強度の 変動係数が異なるとした場合に定性的に説明できること がわかった，今回のばねモデルでは，ばねの強度の変動係 数が小さい場合には．2段のばねのうち 1 段に破壊が集中 するという傾向がみられた。このため，ばねの強度の変動 係数が無限に小さくなる場合の，ピーク応力以降のひず みの減少量の累積值を正規化した值は理論上 0.5 になる. この值は, Table 3 に示した值である $0.756 〜 0.575$ に比 べて小さい，よって，本ばねモデルでは破壊応力以降の ひずみの減少量を定量的には説明できていない，定量的 な説明のためには，本ばねモデルに何らかの改良を行う 必要があるが，これについては今後の課題としたい.

\section{$4 \cdot 4$ 破壊強度以降のひずみの増加について}

破壊強度以降に扎いて，応力が低下しながらひずみが 減少する現象等は, 前述のばねモデルで説明できること がわかった。しかし，破壊強度以降においては，Fig. 5 に示したように，ひずみの増加と減少を繰り返しながら 応力が低下し, 安定してひずみが増加する残留強度へと 達する。ここでは，ひずみの増加について考えてみる。 Fig. 5 に示した破壊強度後の時間一ひずみ曲線において， ひずみが増加する際の勾配（単位時間当たりのひずみの 増加量）を求めた結果を Fig. 10 に示す.ばらつきが大き いが，残留強度状態に至るまでの勾配の平均值を求めた 結果は， $3.7 \times 10^{-6} / \mathrm{s}$ であり，残留強度状態の勾配である $3.5 \times 10^{-6} / \mathrm{s}$ とほほ等しい值であることがわかった。この ことから, 破壊強度以降の破壊が進行している段階にお いても残留強度状態とほぼ同様に, ひずみの増加が生じ ているものと推察される.

\section{5 結}

\section{言}

本研究では，Class II 岩石の一つである稲田花崗岩を 用いて，応力帰還法による一軸圧縮試験を実施した。本 研究で得られた結果をまとめると以下のとおりである.

（1）石の目に対する載荷方向扎よび含水状態を変えた 試験を実施し, 完全応力ーひずみ曲線を計測した.

（2）単純なばねモデルにより破壊強度以降も含めた応 


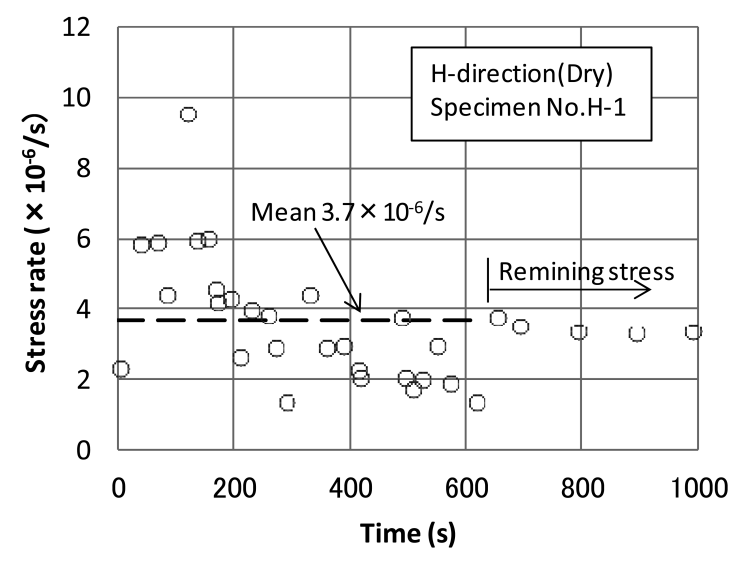

Fig. 10 Stress rate of post-failure reegion.

カーひずみ曲線のシミュレーションを実施し，石の目に 対して載荷方向が異なることによる異方性や含水状態が 応力ーひずみ挙動に及ぼす影響について考察を行った。 その結果，ばねの強度の変動係数が異なるとすることで, 載荷方向異方性や含水状態が応力ーひずみ挙動に及ぼす 影響を説明できることがわかった。

\section{参 考 文 献}

1) W. R. Wawersik and C. Fairhurst, "A study of brittle rock fracture in laboratory compression experiments”, International Journal of Rock Mechanics and Mining Science, Vol.7, pp.561-575 (1970).

2 ) Y. Hiramatsu, Y. Oka, Y. Mizuta, T. Saito and K. Sugawara, "The deformation behavior of rocks after failure and consideration about the mechanism of burst of pillars", Nihonkougyoukai-shi, Vol.90, No.1036, pp.399-404 (1974).

3 ) S. Okubo, C. He and Y. Nishimatsu, "Time dependent behavior in uniaxial compression -Rheological behavior of rock in post-failure region (1st report)-”, Nihon-kougyoukaishi, Vol.103, No.1189, pp.177-181 (1988).

$4)$ C. He, S. Okubo and Y. Nishimateu, "Loading rate dependency of class II rock under confining pressure”, Journal of the Society of Materials Science, Japan, Vol.38, No.426, pp.216-220 (1989).

5 ) Y. Inada and Y. Kokudo, "Effect of high and low temperature on failure characteristics of rocks under compression”, Journal of the Society of Materials Science, Japan, Vol.41, No.463, pp.410-416 (1992).
6) T. Saito, Y. Hasui and O. Nishii, "Post-failure behavior in triaxial compression test controlled by radial deformation", Proceedings of the 15th Symposium on Rock Mechanics, pp.40-44 (1986).

7) A. Cho and H. Kawakata, "A high-pressure, high-temperature rock testing appararus installed at the geological survey of Japan -The axial stress drop process in the post-failure region of Westerly granite-", Bulletin of the Geological Survey of Japan, Vol.48 (8), pp.459-468 (1997).

$8)$ Y. Kudo, K. Hashimoto, O. Sano and K. Nakagawa, "Relation between physical anisotropy and microstructure og granite", Journals of the Japan Society of Civil Engineers, No.370, III-5, pp.189-198 (1986).

9) T. Yanagidani, S. Nishiyama and M. Terada, "Anisotropic development of dilatancy in uniaxially compressed granite", Journals of the Japan Society of Civil Engineers, No.382, III-7, pp.63-72 (1987).

10) O. Sano, Y. Kudo, Y. Mizuta and K. Nakagawa, "Deformation and fracture process of granitic rocks as an anisotropic body”, Journals of the Japan Society of Civil Engineers, No.400, III-10, pp.179-188 (1988).

11) Y. Inada, N. Kinoshita, S. Seki, T. Matsuo, A. Nariyuki and K Ochi, "A few remarks on thermal behavior of rock mass around openings affected by low temperature", Journals of the Japan Society of Civil Engineers, No.547, III-36, pp.211-220 (1996).

12) Y. Inada, K. Yokota and T. Tokikawa, "Effect of heated water on strength and deformation characteristic of rocks", Journals of the Japan Society of Civil Engineers, No.370, III-5, pp.217-223 (1986).

13) O. Sano, Y. Kudo, Y. Mizuta and K. Nakagawa, "Deformation and fracture process of granitic rocks as an anisotoropic body”, Journals of the Japan Society of Civil Engineers, No.400, III-10, pp.179-188 (1988).

14) Nihon-zairyou-gakkai-hen, "Iwano rikigaku kiso kara ouyou made”, pp.100-101 (1993) Maruzen.

15) C. He, S. Okubo and Y. Nishimatsu, "A study on the class II behavior of rock”, Shigen-sozai-gakkai-shi, Vol.105, No.8, pp.591-596 (1989). 